\title{
PERSEPSI MASYARAKAT TERHADAP KEBERADAAN HUTAN MANGROVE DI DESA SUNGAI KUNYIT LAUT KABUPATEN MEMPAWAH
}

(The People Perception for the Existence Mangrove Forest in The Village Sungai Kunyit Laut District Mempawah)

Loira Lifma Haloho, Eddy Thamrin, Iswan Dewantara

Fakultas Kehutanan Universitas Tanjungpura Pontianak. J1. Daya Nasional Pontianak 78124

E-mail : loiralifma@gmail.com

\begin{abstract}
Mangrove ecosystems are the wetland resources of the region and the life support system and high value natural wealth, therefore it is necessary to protect, preserve and sustainably use for the welfare of the community. The purpose of this study was to determine the public perception of the existence of a mangrove forest in the Sungai Kunyit Laut village, Mempawah district and factors that influence. The method based on survey and sampling techniques or interviews the respondents conducted by purposive sampling. The number of respondents were 79 respondents. The results showed the level of public perception to the existence of a mangrove forest in the Sungai Kunyit laut village tend to be higher as many as 62 respondents $(78,48 \%)$ have a high perception of the existence of a community forest in the Sungai Kunyit Laut village, 16 respondents $(20,25 \%)$ perceive moderate and 1 responden $(1,27 \%)$ respondents who had a low perception. And the analysis shows that the level of education, income and cosmopolitan do not have a correlation with the level of public perception to the existence of a mangrove forest. But the level of age have a correlation with people's perception of the existence of mangrove forest.
\end{abstract}

Keywords: District Mempawah, Mangrove forests, Public perception

\section{PENDAHULUAN}

Peraturan Presiden Republik

Indonesia Nomor 73 tahun 2012 Tentang Strategi Nasional Pengelolaan Ekosistem Mangrove Presiden Republik Indonesia menimbang bahwa ekosistem mangrove merupakan sumberdaya lahan basah wilayah pesisir dan sistem penyangga kehidupan dan kekayaan alam yang nilainya sangat tinggi, oleh karena itu perlu upaya perlindungan, pelestarian dan pemanfaatan secara lestari untuk kesejahteraan masyarakat.

Hutan mangrove dan masyarakat yang bermukim di sekitarnya merupakan dua komponen yang saling mempengaruhi. Interaksi di antara keduanya merupakan suatu hal yang tidak dapat dihindarkan karena mereka berada dalam lingkungan yang sama. Aktivitas, pandangan atau tindakan masyarakat sekitar hutan mangrove dapat mempengaruhi keberlanjutan keberadaan dan kelestarian hutan mangrove tersebut.

Pertumbuhan penduduk yang tinggi dan meningkatnya kegiatan pembangunan di pesisir bagi berbagai peruntukkan menyebabkan terjadinya tekanan ekologis terhadap ekosistem pesisir khususnya ekosistem mangrove. Meningkatnya tekanan ini akan 
berdampak terhadap kerusakan hutan mangrove baik secara langsung (kegiatan penebangan dan konversi lahan) maupun secara tidak langsung (pencemaran atau limbah berbagai kegiatan pembangunan pelabuhan) (Alimuna, 2009).

Penelitian ini bertujuan untuk mengetahui persepsi masyarakat terhadap keberadaan Hutan Mangrove di Desa Sungai Kunyit Laut Kabupaten Mempawah, serta menganalisis faktorfaktor yang mempengaruhinya.

\section{METODE PENELITIAN}

Penelitian ini dilaksanakan di Desa Sungai Kunyit Laut Kecamatan Sungai Kunyit Kabupaten mempawah, Kalimantan Barat. Metode yang digunakan adalah metode survey dengan teknik wawancara dan alat yang digunakan untuk pengumpulan data ialah kuisioner. Objek yang diteliti adalah masyarakat yang berada di sekitar hutan mangrove Desa Sungai Kunyit Laut Kecamatan Sungai Kunyit Kabupaten mempawa. Teknik pengam bilan sampel adalah dengan cara purposive sampling (Sugiyono,2010).

Kriteria masyarakat yang akan dijadikan responden dalam penelitian ini adalah: (1) Kepala Keluarga (2) Aktif bekerja dan (3) Sehat jasmani dan Rohani
Data yang dikumpulkan ialah Data primer berupa Identitas Responden, Persepsi Masyarakat Terhadap Hutan Mangrove, Umur, Pendidikan, pendapatan dan Kosmopolitan Masyarakat Terhadap Keberadaan Hutan Mangrove. Data sekunder yaitu berupa data statistik, peta, kondisi umum lokasi penelitian dan literaturliteratur yang mendukung dan tekait dengan penelitian.

Data yang diperoleh ditabulasikan dan kemudian dianalisis dengan menggunakan Chi Square. Rumus dasar yang digunakan adalah rumus dibawah ini : (Sugiyono, 2017).

$$
X^{2}=\sum_{i=1}^{k} \frac{\left(f_{o}-f_{h}\right)^{2}}{f_{h}}=>\quad f_{h}=\frac{\sum N}{\sum K}
$$

HASIL DAN PEMBAHASAN

\section{Persepsi Masyarakat Terhadap Keberaan Hutan Mangrove}

Hasil penelitian Persepsi Masyarakat Terhadap Keberadaan Hutan Mangrove Di Desa Sungai Kunyit Laut Kabupaten Mempawah yang berjumlah 79 Responden diperoleh hasil 62 responden $(78,48 \%)$ bersifat Positif, 16 responden $(20,25 \%)$ bersifat Netral dan 1 responden $(1,27 \%)$ bersifat Negatif terhadap keberadaan Hutan Mangrove dan diuraikan dalam tabel berikut: 


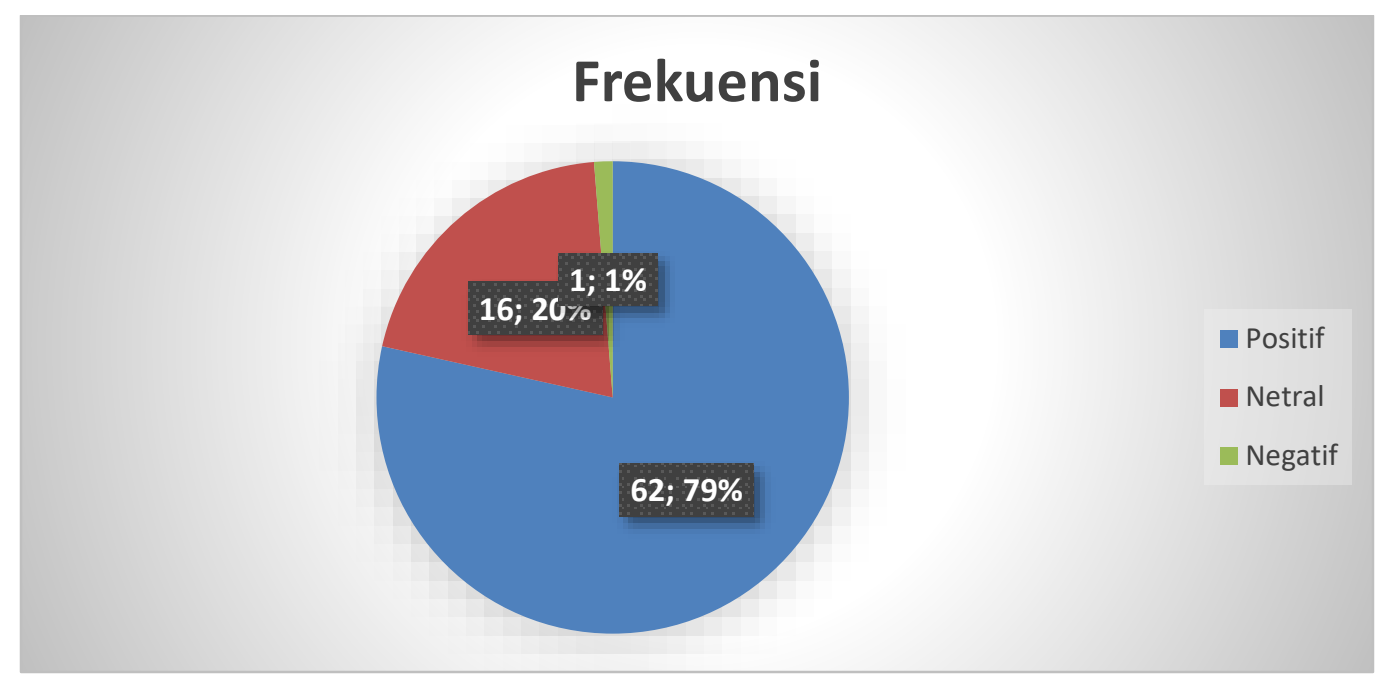

Gambar 1. Diagram Frekuensi Responden Berdasarkan Persepsi Masyarakat Terhadap Keberadaan Hutan Mangrove di Desa Sungai Kunyit Laut Kabupaten Mempawah (Frequency diagram of Respondents Based on Public Perception of Existence of Mangrove Forest in the Sungai Kunyit Laut Village, Mempawah District)

Persepsi masyarakat disekitar hutan mangrove berupa persepsi positif dan negatif. Persepsi masyarakat tersebut dipengaruhi oleh intensitas dan sifat hubungan antara masyarakat dengan hutan mangrove, apakah selama ini segala aktifitas dan interaksi masyarakat dengan hutan mangrove memberikan manfaat yang nyata kepada masyarakat atau sebaliknya.

Hasil Uji Chi square $\left(\mathrm{X}^{2}\right)$ data persepsi responden terhadap keberadaan hutan mangrove diperoleh nilai $x_{\text {hitung }}^{2}>x_{\text {tabel }(0,05)}^{2}$ nilai $\quad x_{\text {hitung }}^{2}$ sebesar 76,73. Sedangkan nilai $\mathrm{x}_{\text {tabel }}^{2}(0,05)$ dengan derajad bebas (Db) 2 adalah 5,911. Dengan demikian disimpulkan bahwa terdapat perbedaan yang signifikan frekuensi persepsi masyarakat terhadap keberadaan hutan mangrove di desa mereka.

Persepsi adalah proses internal yang mana telah diakui oleh individu ketika menyeleksi dan mengatur stimuli yang berasal dari luar. Stimuli ini ditangkap oleh indera yang dimiliki seseorang, kemudian secara spontan perasaan dan pikiran individu akan memberikan makna dari stimuli yang ada tersebut. Secara sederhana, dapat dikatakan jika persepsi adalah proses individu dalam memahami hubungan atau kontak dengan dunia yang ada di sekelilingnya (Suranto Aw, 2010). Masyarakat yang memiliki pandangan yang baik terhadap keberadaan hutan mangrove cenderung akan memiliki persepsi yang positif terhadap keberadaan hutan mangrove dibandingkan dengan masyarakat yang mempunyai pandangan yang tidak baik. Diagram 1 menunjukkan bahwa masyarakat di sekitar hutan mangrove dominan memiliki pandangan yang positif. Hal ini dikarenakan masyarakat menyadari dan merasakan peran dan 
manfaat dari hutan mangrove yang ada di desa mereka baik yang dirasakan secara langsung maupun tidak langsung.

Responden yang memiliki persepsi cenderung netral adalah masyarakat yang masih ragu-ragu dalam menentukan sikap terhadap peran hutan mangrove. Hal ini dikarenakan responden kurang mengetahui maupun kurang menyadari tentang manfaat yang diberikan oleh hutan mangrove kepada masyarakat. Atas dasar itu, kelompok masyarakat ini masih meragukan yakni pada kondisi tertentu menerima keberadaan hutan mangrove, dan pada kondisi lainnya tidak menerima keberadaan hutan mangrove di desa mereka.

Persepsi masyarakat terhadap keberadaan hutan mangrove dipengaruhi oleh beberapa faktor internal maupun faktor eksternal dari masyarakat tersebut, yakni: (1) Faktor Umur; (2) Faktor Pendidikan; (3) Faktor Pendapatan dan (4) Faktor kosmopolitan.

\section{Faktor Umur}

Salah satu faktor utama yang mempengaruhi efisiensi belajar seseorang yaitu umur karena akan berpengaruh terhadap motivasi belajar seseorang. Masyarakat yang berumur muda pada umumnya mempunyai keingin tahuan yang tinggi, sehingga mereka lebih peka terhadap permasalahan yang ada. Untuk melihat hubungan antara tingkat umur dengan persepsi masyarakat terhadap keberadaan hutan mangrove di desa Sungai Kunyit dapat dilihat pada tabel berikut:

Tabel 1. Hubungan Tingkat Umur dengan Persepsi Masyarakat Terhadap Keberadaan Hutan Hutan Mangrove di Desa Sungai Kunyit Laut Kabupaten Mempawah (Age Level connection with Public Perception of Existence of Mangrove Forest in the Sungai Kunyit Laut Village, Mempawah District)

\begin{tabular}{|c|c|c|c|c|c|c|c|}
\hline \multirow[t]{2}{*}{ Persepsi } & \multicolumn{6}{|c|}{ Umur } & \multirow[t]{2}{*}{ Total } \\
\hline & $20-34$ & $\%$ & $35-49$ & $\%$ & $50-64$ & $\%$ & \\
\hline Positif & 7 & 58.33 & 31 & 77.50 & 24 & 88.89 & 62 \\
\hline Netral & 4 & 33.33 & 9 & 22.50 & 3 & 11.11 & 16 \\
\hline Negatif & 1 & 8.33 & 0 & 0 & 0 & 0 & 1 \\
\hline JUMLAH & 12 & 100 & 40 & 100 & 27 & 100 & 79 \\
\hline
\end{tabular}

Setelah dilakukan analisis chi square diperoleh nilai $\mathrm{x}_{\text {hitung }}^{2}$ sebesar 32,74. Sedangkan nilai $x_{\text {tabel }}^{2}(0,05)$ dengan derajad bebas (Db) 4 adalah 9,488 yang berarti $x_{\text {hitung }}^{2} \geq$ $\mathrm{x}_{\text {tabel }(0,05)}^{2}$. Dapat diambil kesimpulan bahwa terdapat pengaruh yang nyata dengan persepsi masyarakat terhadap keberadaan hutan mangrove.

Dominan umur responden yang diambil yaitu umur 35-64 tahun yaitu berjumlah 67 orang, dimana umur tersebut oleh Djojohadikusumo (1994) dikategorikan dalam kelompok dewasa dan tua. Dari hasil penelitian diatas 
dapat diketahui bahwa umur memiliki hubungan yang sangat nyata dengan persepsi masyarakat terhadap keberadaan hutan mangrove di Desa Sungai Kunyit Laut. Harsojo (1996) mengungkapkan bahwa umur tidak menentukan kedewasaan seseorang dalam bertindak, dikarenakan setiap orang tidak memiliki karakter yang sama untuk dijadikan dalam suatu tingkatan yang lebih spesifiuk.

Umur memiliki hubungan yang nyata terhadap persepsi masyarakat dikarenakan umur responden banyak masuk kedalam usia yang sudah matang dimana pada usia ini sudah banyak pengalaman-pengalaman yang tentunya dapat memberikan nilai-nilai positif terhadap pola pikir masyarakat. Pemahaman akan nilai-nilai positif dari keberadaan hutan mangrove yang dimiliki responden pada usia matang tidak dapat disamakan dengan responden yang masih berusia muda. Berdasarkan pemahaman tersebut sehingga pada penelitian ini umur memiliki hubungan yang nyata terhadap persepsi masyarakat terhadap keberadaan hutan mangrove di desa Sungai Kunyit Laut.

\section{Faktor Pendidikan}

Faktor pendidikan dikelom-pokkan kedalam 4 kelompok yaitu Tidak Sekolah (TS), Tidak Lulus SD - Lulus SD, Tidak Lulus SMP - Lulus SMP dan Tidak Lulus SMA - Lulus SMA. Untuk melihat hubungan antara tingkat pendidikan dengan persepsi masyarakat terhadap keberadaan hutan mangrove di desa Sungai Kunyit dapat dilihat pada tabel berikut:

Tabel 2. Hubungan Tingkat Pendidikan dengan Persepsi Masyarakat Terhadap Keberadaan Hutan Mangrove di Desa Sungai Kunyit Laut Kabupaten Mempawah (Education Level connection with Public Perception of Existence of Mangrove Forest in the Sungai Kunyit Laut Village, Mempawah District)

\begin{tabular}{|c|c|c|c|c|c|c|c|c|c|}
\hline \multirow[t]{2}{*}{ Persepsi } & \multicolumn{8}{|c|}{ Pendidikan } & \multirow[t]{2}{*}{ Total } \\
\hline & TS & $\%$ & SD & $\%$ & SMP & $\%$ & SMA & $\%$ & \\
\hline Positif & 3 & 100 & 15 & 62.5 & 23 & 85.19 & 21 & 84.00 & 62 \\
\hline Netral & 0 & 0 & 9 & 37.5 & 4 & 14.81 & 3 & 12.00 & 16 \\
\hline Negatif & 0 & 0 & 0 & 4 & 0 & 0.00 & 1 & 4.00 & 1 \\
\hline JUMLAH & 3 & 100 & 24 & 100 & 27 & 100 & 25 & 100 & 79 \\
\hline
\end{tabular}

Setelah dilakukan analisis chi square diperoleh nilai $\mathrm{x}_{\text {hitung }}^{2}$ sebesar 8.71. Sedangkan nilai $x_{\text {tabel }(0,05)}^{2}$ dengan derajad bebas (Db) 4 adalah 9,488 yang berarti $\mathrm{x}_{\text {hitung }}^{2}<$ $\mathrm{x}_{\text {tabel }}^{2}(0,05)$. Dapat diambil kesimpulan bahwa tidak terdapat pengaruh yang nyata dengan persepsi masyarakat terhadap keberadaan hutan mangrove.

Dalam hal ini pendidikan tidak memiliki hubungan yang erat dengan persepsi masyarakat terhadap keberadaan hutan mangrove di Desa 
Sungai Kunyit Laut. Tingkat pendidikan masyarakat di desa Sungai Kunyit pada umumnya rendah yaitu mayoritas SD hingga SMP. Oleh karena banyaknya penduduk yang berpendidikan rendah sehingga pendidikan tidak memiliki hubungan yang erat dengan persepsi masyarakat terhadap keberadaan hutan mangrove di Desa Sungai Kunyit.

Persepsi masyarakat yang tinggi terhadap keberadaan hutan mangrove yaitu disebabkan oleh masyarakat yang menjadi responden mayoritas penduduk asli ataupun pendatang yang sudah bermukim lama di desa Sungai Kunyit dan sudah bersentuhan langsung dengan hutan mangrove. Oleh karena itu sudah menjadi kebiasaan dan menjadi tradisi bagi masyarakat setempat untuk menjaga dan melestarikan hutan mangrove. Adat dan kebiasan yang telah mentradisi dilakukan oleh sekelompok masyarakat ini biasa disebut dengan kearifan lokal. Kearifan lokal adalah pandangan hidup dan ilmu pengetahuan serta berbagai strategi kehidupan yang berwujud aktivitas yang dilakukan oleh masyarakat lokal dalam menjawab berbagai masalah dalam pemenuhan kebutuhan mereka. Dalam bahasa asing sering juga dikonsepsikan sebagai kebijakan setempat local wisdom atau pengetahuan setempat "local knowledge" atau kecerdasan setempat local genious (Fajarini, 2014).

\section{Faktor Pendapatan}

Mata pencaharian penduduk Sungai Kunyit Laut pada umumnya adalah Nelayan, pedagang ikan dan petani. Dari sebaran pendapatan masyarakat Sungai Kunyit Laut dikelompokkan menjadi 3 yaitu tinggi, sedang dan rendah. Untuk melihat hubungan antara tingkat pendapatan dengan persepsi masyarakat terhadap keberadaan hutan mangrove di desa Sungai Kunyit dapat dilihat pada tabel berikut:

Tabel 3. Hubungan Tingkat Pendapatan dengan Persepsi Masyarakat Terhadap Keberadaan Hutan Mangrove di Desa Sungai Kunyit Laut Kabupaten Mempawah (Income Level connection with Public Perception of Existence of Mangrove Forest in the Sungai Kunyit Laut Village, Mempawah District)

\begin{tabular}{|c|c|c|c|c|c|c|c|}
\hline \multirow[t]{2}{*}{ Persepsi } & \multicolumn{6}{|c|}{ Pendapatan } & \multirow[t]{2}{*}{ Total } \\
\hline & Tinggi & $\%$ & Sedang & $\%$ & Rendah & $\%$ & \\
\hline Positif & 16 & 72.73 & 0 & 0 & 46 & 82.14 & 62 \\
\hline Netral & 5 & 22.73 & 1 & 100 & 10 & 17.86 & 16 \\
\hline Negatif & 1 & 4.55 & 0 & 0 & 0 & 0 & 1 \\
\hline JUMLAH & 22 & 100.00 & 1 & 100 & 56 & 100.00 & 79 \\
\hline
\end{tabular}

Setelah dilakukan analisis chi square diperoleh nilai $\mathrm{x}_{\text {hitung }}^{2}$ sebesar 6,96 . Sedangkan nilai $x_{\text {tabel }}^{2}(0,05)$ dengan derajad bebas (Db) 4 adalah 9,488 yang berarti $x_{\text {hitung < }}^{2}$ $\mathrm{x}_{\text {tabel }(0,05)}^{2}$. Dapat diambil kesimpulan 
bahwa tidak terdapat pengaruh yang nyata dengan persepsi masyarakat terhadap keberadaan hutan mangrove

Pendapatan adalah sejumlah penghasilan yang diperoleh masyarakat atas prestasi kerjanya dalam periode tertentu, baik harian, mingguan, bulanan maupun tahunan (Sukirno, 2006). Rahardja dan Manurung (2001) mengemukakan pendapatan adalah total penerimaan (uang dan bukan uang) seseorang atau suatu rumah tangga dalam periode tertentu. Berdasarkan kedua definisi tersebut, dapat disimpulkan bahwa pendapatan merupakan penghasilan yang diterima oleh masyarakat berdasarkan kinerjanya, baik pendapatan uang maupun bukan uang selama periode tertentu, baik harian, mingguan, bulanan maupun tahunan

Dari hasil penelitian diketahui masyarakat yang mengisi kuisioner mayoritas berpendapatan rendah yaitu 56 responden atau $70,89 \%$ dari total keseluruhan responden. Pendapatan tidak memiliki hubungan yang erat dengan persepsi masyarakat terhadap keberadaan hutan mangrove. Hal ini terjadi karena masyarakat pada umumnya bekerja sebagai nelayan dan bertani.

Pendapatan nelayan berasal dari dua sumber, yaitu pendapatan dari usaha penangkapan ikan dan pendapatan dari luar usaha penangkapan ikan. Sumber pendapatan utama bagi nelayan yaitu berasal dari usaha penangkapan ikan sedangkan pendapatan dari luar usaha penangkapan ikan, biasanya lebih rendah (Sajogyo 1996). Dapat diartikan bahwa masyarakat lebih fokus pada pekerjaan sebagai nelayan dan tidak memanfaatkan hutan mangrove untuk menghasilkan uang. Masyarakat tidak memanfaatkan hutan mangrove untuk kepentingan ekonomi. Dengan kata lain hutan mangrove tidak memiliki nilai ekonomi bagi masyarakat disekitarnya sehingga pendapatan dan jenis pekerjaan masyarakat tidak berpengaruh dengan persepsi masyarakat terhadap keberadaan hutan mangrove di Desa Sungai Kunyit Laut.

\section{Faktor Kosmopolitan}

Berdasarkan Kamus Besar Bahasa Indonesia, Kosmopolitan berarti mempunyai wawasan dan pengetahuan yang luas. Dalam hal ini kosmopolitan dapat diartikan bahwa tingginya atau luasnya pengetahuan maupun wawasan responden mengenai hutan mangrove. Untuk melihat hubungan antara tingkat kosmopolitan dengan persepsi masyarakat terhadap keberadaan hutan mangrove di desa Sungai Kunyit dapat dilihat pada tabel berikut: 
Tabel 4. Hubungan Tingkat Kosmopolitan dengan Persepsi Masyarakat Terhadap Keberadaan Hutan Mangrove di Desa Sungai Kunyit Laut Kabupaten Mempawah (Cosmopolitan Level connection with Public Perception of Existence of Mangrove Forest in the Sungai Kunyit Laut Village, Mempawah District)

\begin{tabular}{|c|c|c|c|c|c|c|c|}
\hline \multirow[t]{2}{*}{ Persepsi } & \multicolumn{6}{|c|}{ Kosmopolitan } & \multirow[t]{2}{*}{ Total } \\
\hline & Tinggi & $\%$ & Sedang & $\%$ & Rendah & $\%$ & \\
\hline Positif & 8 & 66.67 & 36 & 83.72 & 18 & 75.00 & 62 \\
\hline Netral & 4 & 33.33 & 6 & 13.95 & 6 & 25.00 & 16 \\
\hline Negatif & 0 & 0.00 & 1 & 2.33 & 0 & 0 & 1 \\
\hline JUMLAH & 12 & 100.00 & 43 & 100 & 24 & 100.00 & 79 \\
\hline
\end{tabular}

Setelah dilakukan analisis chi square diperoleh nilai $\mathrm{x}_{\text {hitung }}^{2}$ sebesar 3,37 . Sedangkan nilai $x_{\text {tabel }(0,05)}^{2}$ dengan derajad bebas $(\mathrm{Db}) 4$ adalah 9,488 yang berarti $x_{\text {hitung }}^{2}<x_{\text {tabel }(0,05)}^{2}$. Dapat diambil kesimpulan bahwa tidak terdapat pengaruh yang nyata dengan persepsi masyarakat terhadap keberadaan hutan mangrove.

Dari hasil penelitian diketahui bahwa tingkat kosmopolitan tidak memiliki hubungan yang erat dengan persepsi masyarakat. Diketahui pula bahwa tingkat kosmopolitan yang paling tinggi yaitu tingkat sedang yaitu berjumlah 43 responden atau 54,43\% dari total keseluruhan responden.

Tingkat kosmopolitan tidak memiliki hubungan yang nyata dengan persepsi masyarakat terhadap keberadaan hutan mangrove, hal ini berkaitan dengan umur responden. Seperti diketahui dari hasil penelitian umur responden mayoritas umur dewasa hingga lansia. Pambudi, (2001) menyatakan Kosmopolitan adalah tingkat kemampuan seseorang dalam mencari informasi pengetahuan berupa pengalaman melihat, mendengar, membaca (media massa, cetak maupun elektronik) "bergaul” maupun bepergian ke suatu tempat sehingga dapat menambah pengalaman dalam memecahkan masalah dan perubahan perilaku pribadinya. Pada usia dewasa hingga lansia, dalam penelitian ini yaitu usia 35 tahun hingga 64 tahun merupakan usia yang produktif bekerja dan juga pada usia ini masyarakat kurang tertarik dengan media informasi yang ada belakangan ini.

Tingkat kosmopolitan sedang berarti responden menjawab ragu-ragu pertanyaan kuisioner. Dengan kata lain responden ragu-ragu dengan pengetahuan ataupun wawasan yang mereka miliki. Dapat dikatakan juga bahwa banyak responden yang tidak paham mengenai informasi yang ada ataupun masyarakat kurang peduli atau kurang mengikuti perkembangan informasi yang telah ataupun sedang terjadi.

Salah satu faktor lainnya yang menyebabkan kosmopolitan tidak berpengaruh dengan persepsi masyarakat terhadap keberadaan hutan 
mangrove adalah masih minimnya penyuluhan-penyuluhan mengenai manfaat dan pentingnya pelestarian hutan mangrove di desa tersebut.

\section{Kesimpulan}

1. Persepsi masyarakat terhadap keberadaan hutan mangrove di Desa Sungai Kunyit Laut sebagian besar berpandangan positif. Hal ini merupakan suatu gambaran bahwa masyarakat desa Sunyai Kunyit Laut merasakan secara langsung manfaat dari keberadaan hutan mangrove di desa mereka.

2. Faktor umur memiliki hubungan yang nyata dengan persepsi masyarakat terhadap keberadaan hutan mangrove di desa Sungai Kunyit Laut Sedangkan faktor pendidikan, tingkat pendapatan dan tingkat kosmopolitan tidak memiliki hubungan yang nyata dengan persepsi masyarakat terhadap keberadaan hutan mangrove di desa Sungai Kunyit Laut, Kabupaten Mempawah.

\section{Saran}

Sebaiknya dilakukan penyuluhanpenyuluhan mengenai hutan mangrove untuk menambah pengetahuan dan wawasan masyarakat di sekitar hutan mangrove

\section{DAFTAR PUSTAKA}

Alimuna Wa, Sunarto dan Herumurti Sigit. 2009. Pengaruh Aktivitas Masyarakat Terhadap Kerusakan Hutan Mangrove Di Rarowatu Utara Bombana Sulawesi
Tenggara. Majalah Geografi Indonesia. 23 (2) : 142-153.

Suranto Aw. 2010. Komunikasi Interpersonal. Graha Ilmu. Yogyakarta.

Djojohadikusumo, $\quad$ S. 1994. Perkembangan Pemikiran Ekonomi: Dasar Teori Ekonomi Pertumbuhan dan Ekonomi Pembangunan. LP3ES. Jakarta.

Fajarini,Ulfah. 2014. Peranan Kearifan Lokal Dalam Pendidikan Karakter. Jurnal Sosio Didaktika; 1 (2) : 123-130.

Harsojo. 1967 .Pengantar Antropologi., Binacipta. Bandung.

Pambudi, T. S. 2001. Wajah Murung Komitmen Karyawan. SWA sembada: 14 (17).

Rahardja Prathama dan Mandala Manurung. 2001. Teori Ekonomi Makro. Fakultas Ekonomi Universitas Indonesia.

Republik Indonesia. 2012. Peraturan Presiden Republik Indonesia Nomor 73 Tahun 2012 Tentang "Strategi Nasional Pengelolaan Ekosistem Mangrove. Sekretariat Kabinet RI. Jakarta.

Sugiyono. 2010. Metode Penelitian Kuantitatif Kualitatif dan $R \& D$. Alfabeta. Bandung.

Sugiyono. 2017. Statistika Untuk Penelitian. Alfabeta. Bandung.

Sukirno. 2006. Makroekonomi: Teori Pengantar. Raja Grafindo Persada. Jakarta.

Sajogyo, 1996. Pengembangan Daerah dan Pemberdayaan Masyarakat. Bina Rena Pariwara. Jakarta. 